\title{
ABO blood group system
}

\author{
Gradimir Misevic ${ }^{1,2 *}$ \\ ${ }^{1}$ Department of Informatics, University of Brest, Brest 29238, France \\ ${ }^{2}$ Research and Development, Gimmune GmbH, Baarerstrasse, Zug 6301, Switzerland
}

\begin{abstract}
The ABO blood group system in humans has three different carbohydrate antigens named A, B, and $\mathrm{O}$. The A antigen sequence is terminal trisaccharide $\mathrm{N}$-acetylgalactosamine (GalNAc) $\alpha 1-3$ [Fuc $\alpha 1-2] \mathrm{Gal} \beta-$, B is terminal trisaccharide Gal $\alpha$ l-3[Fuc $\alpha$ l-2]Gal $\beta$-, and $\mathrm{O}$ is terminal disaccharide Fuc $\alpha$ l-2Gal $\beta$-. The single ABO gene locus has three alleles types $\mathrm{A}, \mathrm{B}$ and $\mathrm{O}$. The $\mathrm{A}$ and $\mathrm{B}$ genes code $\mathrm{A}$ and $\mathrm{B}$ glycosyltransferases respectively and $\mathrm{O}$ encodes an inactive enzyme. A large allelic diversity has been found for A and B transferases resulting in the genetic subgrouping of each $\mathrm{ABO}$ blood type. Genes for both transferases have been cloned and the 3D structure of enzymes with and without substrate has been revealed by NMR and X ray crystallography. The ABO blood group system plays a vital role in transfusion, organ and tissue transplantation, as well as in cellular or molecular therapies.
\end{abstract}

Keywords: ABO, blood groups, glycosyltransferase. genes, polysaccharides, glycans, carbohydrates, hemolytic diseases

\section{INTRODUCTION}

The first aim of this ABO blood group system review is to provide a comprehensive and easy way for clinicians and scientists, to recapitulate the multidisciplinary knowledge of this subject until the date of this publication (June 2018). Consequently, this review is divided into sections which are covering the diverse science fields for the exploration of the ABO blood group system. The review starts with research on the carbohydrate basis of the $\mathrm{ABO}$ blood groups antigen structures, which belong to the glycobiology field. Following this, genetics are covered, explaining the genes encoding glycosyltransferases, biochemical studies on the biosynthesis mechanism of $\mathrm{ABO}$ antigen structures, cell biology studies covering spatial and temporal expression patterns of $\mathrm{ABO}$ structures and their biological role. Furthermore, biomedical,

*Correspondence to: Gradimir Misevic, Ph.D, Department of Informatics, University of Brest, 20 Avenue Victor le Gorgeu, CEDEX 3, 29238 Brest, France; Research and Development Gimmune GmbH, Baarerstrasse 12, $6301 \mathrm{Zug}$, Switzerland. Tel: + 33-02-98-01-83-81. E-mail: gradimir@gimmune.com analytical, structural and clinical approaches for the determination of $\mathrm{ABO}$ blood group antigens, isoantibodies, genetic patterns of $\mathrm{ABO}$ alleles and subgroups relevant to transfusion, transplantation and hemolytic diseases are described. The end ,this review also provides information about historical facts about discovery of $\mathrm{ABO}$ blood group system antigens, and $\mathrm{A}$ and $\mathrm{B}$ glycosyltransferase, $\mathrm{ABO}$ genes, 3D structures of $\mathrm{ABO}$ antigens, 3D structures of $\mathrm{A}$ and $\mathrm{B}$ glycosyltransferases and future perspectives.

Each section starts with a short and precise summary, followed by extended explanations with literature citations from original articles, specialized and general reviews, as well as from internet data portals and encyclopedias. Due to the fact that the field of $\mathrm{ABO}$ blood group system is very diverse and complex, not all of the subject details could be covered in complete on the limited article size.

The second aim of this review is to inspire readers to better understand and follow the clinically and scientifically important subject of the ABO blood group system.

The third aim is to provide the literature and inter- 
net links that will aid further deeper search, retrieval and reading of the original publications.

\section{BIOCHEMICAL NATURE OF ABO BLOOD GROUP SYSTEM IN HUIMANS}

The biochemical basis of $\mathrm{ABO}$ blood group system in humans is a set of three different terminal carbohydrate antigen structures named A, B and O. Each individual has either $\mathrm{A}$, or $\mathrm{B}$, or $\mathrm{A}$ and $\mathrm{B}$, or $\mathrm{O}$ glycans, Therefore, four blood groups phenotypes termed A, $\mathrm{B}, \mathrm{AB}$ and $\mathrm{O}$ exist in humans. Very large number of structural studies have been performed in the past 60 years which show the sequence of $\mathrm{ABO}$ blood group antigens ${ }^{[1-15]}$.

$\mathrm{ABO}$ is one of the 36 blood group systems in humans. According to the International Society of Blood Transfusion, it is labeled with number No $001^{[1]}$. The ABO system comes under the umbrella of the histoblood group antigens. The main reason for this nameis that if a deference between blood or transplant donor and receiver individuals exists immune reactions with life threatening consequences will be provoked. Therefore, the ABO blood group system is one of the most essential in transfusion and transplantation clinical medicine.

Blood group $\mathrm{A}$ is the terminal trisaccharide $\mathrm{N}-$ acetylgalactosamine (GalNAc) a 1-3[Fuc a 1-2] Gal $\beta{ }^{-2-15]}$. Blood group B is the terminal trisaccharide Gal a 1-3[Fuc a 1-2] Gal $\beta{ }_{-}^{[2-15]}$. The blood group $\mathrm{O}$ is the terminal disaccharide Fuc a $1-2 \mathrm{Gal} \beta{ }_{-}^{[2-15]}$, and is also called $\mathrm{H}$ antigen (see section "Relation between $O$ and $H$ antigens and genes" for more details). These blood groups sequences are shown in Fig. 1 in chemical, schematic and structural form. A useful way to search, visualize and compare these terminal carbohydrate sequences with other glycan motives is via www.glytoucan.org ${ }^{[16]}$, www.unicarbkb.org ${ }^{[17]}$, www.pubchem.ncbi.nlm.nih.gov ${ }^{[18]}$ and on www.ge-

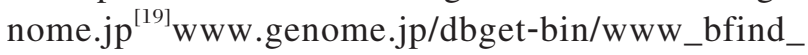
sub?mode=bfind $\&$ max_hit $=1000 \&$ dbkey $=$ glycan $\&$ ke ywords $={ }^{[20]}$.

The carbohydrate nature of the $\mathrm{ABO}$ blood group system invokes that their biosynthesis and sequence are indirectly genetically determined via the expression of glycosyltransferases. Therefore, ABO glycan structures are not directly encoded by genes as protein. Besides ABO blood group system, also Lewis, $\mathrm{H}$ and $\mathrm{P}$ blood group antigens are of carbohydrate nature ${ }^{[1]}$.

Due to the carbohydrate nature of ABO blood group system, classification is based on both glycan structures and genes encoding specific glycosyltransferases that catalyze the biosynthesis of these terminal glycans.

\section{GENES ENCODING GLYCOSYLTRANS- FERASES INVOLVED IN SYNTHESIS OF ABO BLOOD GROUP CARBOHYDRATE ANTIGEN STRUCTURES IN HUMANS}

The single $\mathrm{ABO}$ gene locus in humans has three alleles types A, B and O. Loci A and B encode two different active glycosyltransferases which catalyze the biosynthesis of A and B terminal carbohydrate antigen sequences, using $\mathrm{O}$ antigen carbohydrate structure as a precursor ${ }^{[21}{ }^{31]}$. The $\mathrm{O}$ locus is encoding nonfunctional enzyme ${ }^{[21}{ }^{31]}$. Both A and B enzymes belong to glycosyltransferase family numbered as 6 , according to the HUGO Gene Nomenclature Committee which is the only worldwide authority that assigns standardized nomenclature to human genes ${ }^{[21-22,29]}$.

The human ABO gene is located on chromosome 9 position 34.2 (Fig. 2$)^{[23]}$. The cytogenetic band is termed $9 \mathrm{q} 34.2$. The genomic coordinates are (GRCh38): 9:133,255,175-133,275,213 ${ }^{[21-22,29]}$. This gene belongs to glycosyltransferase family $6^{[21-31]}$. The $\mathrm{ABO}$ gene has 7 exons with exon 7 having the largest coding sequence (Fig. 2 $)^{[21-31]}$. The coding sequence has over 18 kilo base pairsand exons size range be-

Blood group terminal glycan antigen structures

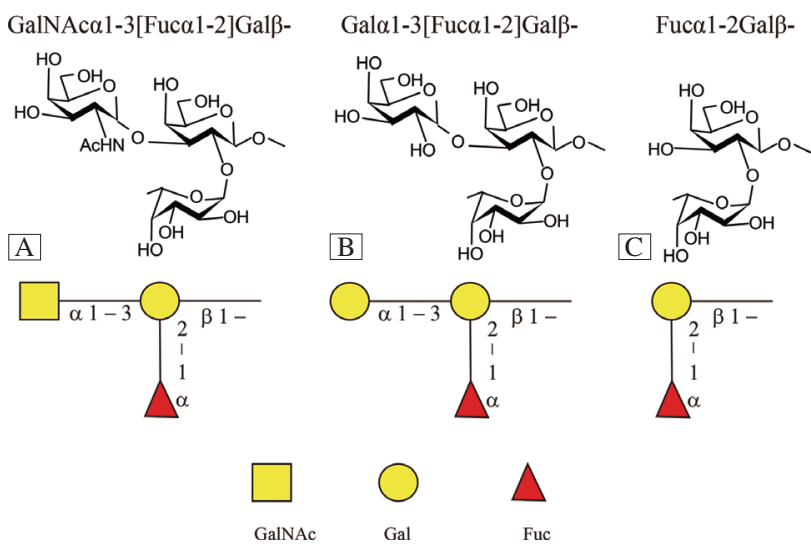

Fig. 1 ABO blood group antigen glycan sequences. $\mathrm{ABO}$ blood group antigen glycan sequences are presented in abbreviated chemical letter form, chemical structural form, and schematic form according to https://glytoucan.org, Gal : galactose; Fuc: fucose; GalNAc: N-acetylgalactosamin.

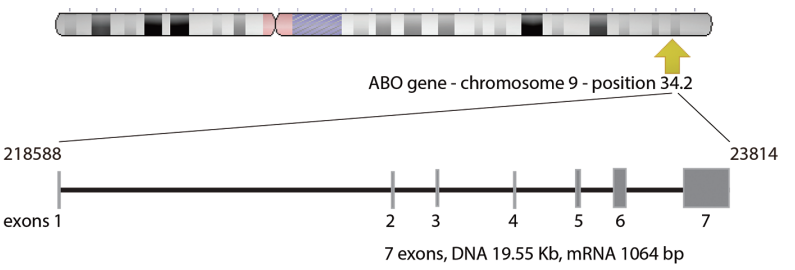

Fig. 2 ABO gene structure. Schematic presentation of $\mathrm{ABO}$ gene chromosomal location and exons positions encoding glycosyltransferase A and B. 
tween 28 to 688 base pairs ${ }^{[21-31]}$.The genes from each $\mathrm{A}$ and $\mathrm{B}$ loci are inherited in pairs as Mendelian codominant. The $\mathrm{O}$ loci is recessive over $\mathrm{A}$ and $\mathrm{B}$ since it does not produce any active glycosyltransferase ${ }^{[21-31]}$.

The A allele encodes transferase A, a 1-3-Nacetylgalactosamyniltransferase. The $\mathrm{B}$ allele encodes transferase B, a 1-3-galactosyltranferase.The single-base substitutions distinguish the $\mathrm{A}$ and $\mathrm{B}$ glycosyltransferases. This results in 4 amino acid substitutions ${ }^{[21-31]}$. The $\mathrm{O}$ allele has guanine deletion at position 258, close to the $\mathrm{N}$-terminuswith the consequence that frameshift occurs resulting in the expression of a different protein without glycosyltransferases catalytic activity ${ }^{[21-31]}$. Individuals with the A alleles express A glycosyltransferase that adds a 1-3-N-acetylgalactosamin to the O glycan structure, also termed $\mathrm{H}$ antigen, resulting in A phenotype blood group $^{[21-31]}$. Individuals with the $\mathrm{B}$ alleles express $\mathrm{B}$ glycosyltransferase that adds a 1-3-galactose(Gal) to the $\mathrm{O}$ glycan structure resulting in $\mathrm{B}$ phenotype blood group $^{[21-31]}$. Individuals with $\mathrm{AB}$ blood group express both A and B glycosyltransferases which are in a codominant way. Therefore, A blood group phenotype can be genetically either a homozygote A/A genotype or heterozygote $\mathrm{A} / \mathrm{O}$ genotype. The same stands for the B blood group phenotype, it can either be a B/B homozygote genotype or a $\mathrm{B} / \mathrm{O}$ heterozygote genotype. The $\mathrm{O}$ phenotype is normally a homozygote genotype unless it is a polymorphism variant, when inactive $\mathrm{A}$ or $\mathrm{B}$ allele is present.

The expression of a particular glycosyltransferase gene encoding specific type of glycosyltransferase that catalyzes the formation of an exact glycosidic linkage, results in the biosynthesis of the four definite carbohydrate sequences $\mathrm{A}$, or $\mathrm{B}$, or $\mathrm{AB}$, or $\mathrm{O}$ giving rise to four distinct blood group phenotypes. Therefore, $\mathrm{ABO}$ blood groups' glycan structure sequences are not directly linked to the gene sequence. In general, glycan structures are secondary gene products and not the primary ones as in proteins where transcription, splicing and translation leads to the biosynthesis of the specific protein. To generate a specific glycan structure, glycosyltransferases (proteins) have to be expressed, and only after the sequential catalysis of their specific (related) glyosidic bonds can a glycan sequence be created. As a consequence, the genetic study and phenotypic expression of $\mathrm{ABO}$ carbohydrate antigens is more complex than that of protein blood groups. It can be therefore, concluded that genetic polymorphism is not necessarily directly connected with terminal glycan structural phenotypic polymorphism.

Genetic studies have shown that the ABO gene polymorphism has reached the number of over 88 different alleles ${ }^{[32]}$. Usually a single nucleotide substitution, resulting in amino acid replacements in glycosyltransferases, is a mechanism generating ABO gene versatility. These phenotypic variants of glycosyltransferases are also confirmed by protein sequencing and serological studies ${ }^{[21-35]}$. The nature of genetic sequence differences of $\mathrm{ABO}$ alleles provides the molecular basis for subgrouping various $\mathrm{ABO}$ alleles into six common alleles; A1, A2, B1, O1, Olv and $\mathrm{O} 2{ }^{[21-35]}$. The A subgroup has actually over 20 different alleles, with $\mathrm{Al}$ being present in about $80 \%$ of $\mathrm{A}$ blood group individuals. A2 accounts for about $20 \%$ of the A population, with the rest of A population being very rare, accounting for less than $1 \%$ of the total. Besides the polymorphism found in coding regions in the $\mathrm{ABO}$ gene, variation in the gene sequences are also detected in the noncoding region; e.g. 21 single nucleotide polymorphism in intron $6^{[21-35]}$. Besides the common alleles, about half of the rear alleles arise through mutations whereas the second half occurs via crossover and gene conversion between alleles that are more common. Therefore, recombinations are as essential as point mutations for creating the diversity of the $\mathrm{ABO}$ gene. Gene structures can be retrieved from internet sites containing additional links to database sites and original literature ${ }^{[21-35]}$.

\section{Relation between $o$ and $h$ antigens and genes}

The $\mathrm{O}$ and $\mathrm{H}$ terminal carbohydrate have the same disaccharide Fuc a 1-2Gal $\beta$ - structure. Therefore, in terms of blood group antigen designation they have an identical phenotype (Fig. 1). However, the ABO gene and the $\mathrm{H}$ gene are different genes. The $\mathrm{H}$ gene belongs to the $\mathrm{H}$ blood group system;designated in the International Society of Blood Transfusion (ISBT) as the No 018, and $\mathrm{ABO}$ as No $001^{[1]}$. The $\mathrm{H}$ gene, (FUT1) encodes a-1,2-fucosyltransferases, catalyzing the biosynthesis of the $\mathrm{H}$ antigen (designated as a cluster of differentiation numbered 173) by adding fucose(Fuc) terminal saccharide to Gal $\beta$ via a 1-2 linkage $\mathrm{e}^{[36-38]}$, The $\mathrm{H}$ carbohydrate antigen structure is the precursor for A and B carbohydrate antigens whose biosynthesis is catalyzed by glycosyltransferases $\mathrm{A}$ and $\mathrm{B}$ (Fig. 2). These are encoded by the $\mathrm{ABO}$ single gene in persons having either $\mathrm{A}$, or $\mathrm{B}$ or $\mathrm{AB}$ genotype. As discussed above, in persons having the $\mathrm{O}$ genotype, the $\mathrm{O}$ allele from the $\mathrm{ABO}$ gene does note encode active glycosyltransferase, leaving the fucose terminal saccharide structure of $\mathrm{H}$ antigen disaccharide unchanged. In conclusion, the fucose terminal saccharide is remains unchanged in persons having the $\mathrm{O}$ blood group, thus $\mathrm{H}$ and $\mathrm{O}$ are same disaccharide glycan antigen structures. 
The cytogenetic chromosomal location of FUT1 gene encoding a-1,2-fucosyltransferases in red blood cells is 19q13.33, with genomic coordinates (GRCh38): 19:48,748,010-48,755,389 ${ }^{[39-40]}$. The FUT2 gene also encodes $\alpha-1,2$-fucosyltransferases, named also as Se secretory locus, was identified with cytogenetic chromosomal location designated as $19 \mathrm{q} 13.33$ and genomic coordinates (GRCh38) 19:48,695,970$48,705,933^{[31,41]}$. This gene regulates expression of $\mathrm{H}$ blood group antigens on the surface of epithelial cells and in body fluids ${ }^{[42]}$.

Rare individuals have been found to have Bombay and para-Bombay phenotypes. These phenotypes are resulting from the mutation in the FUTl gene and the consequential loss of $a-1,2$-fucosyltransferases activity which is characterized by the absence of $\mathrm{H}$ antigen ${ }^{[43]}$. They produce isoantibodies to $\mathrm{O}, \mathrm{B}$ and $\mathrm{A}$ antigens, and thus cannot receive blood from neither $\mathrm{O}$, nor A, nor B blood groups, as these antibodies will bind to $\mathrm{O}$, or $\mathrm{A}$ or $\mathrm{B}$ antigens on the red blood cells of the donor and will induce their lysis by complement mediated reaction ${ }^{[43]}$.

\section{MECHANISM OF ABO BLOOD GROUPS BIOSYNTHESIS}

ABO Blood groups' biosynthesis is achieved via specific set of glycosyltransferases catalyzing the for- mation of specific glycosidic linkages resulting in definite $\mathrm{A}, \mathrm{B}$, or $\mathrm{O}$ carbohydrate sequences. In red blood cells, the biosynthesis of $\mathrm{O}$ disaccharide precedes the A and/or B trisaccharide terminal structure ${ }^{[2-15,24-25,34]}$. The first step is addition of a fucose by the the H-enzyme, encoded by the FUTl gene, to the lactosamine [Gal $\beta$ 1-4-N-acetylglucosamie (GlcNAc) -R] precursor (Fig. 3). The result is the formation of the $\mathrm{H}$ or $\mathrm{O}$ blood group antigen disaccharide terminal structure (note that the whole saccharide is longer and can have different core structures). The A- glycosyltransferase named a 1-3-N-acetylgalactosamyniltransferase catalyzes the a 1-3-N-acetylgalactosamin covalent linking reaction to the $\mathrm{O}$ glycan structure resulting in the blood group A antigen sequence GalNAc a 13 [Fuc a 1-2] Gal $\beta$ - (Fig. 3) ${ }^{[24,25,32]}$. B-glycosyltransferase ( a 1-3-galactosyltranferase) catalyzes the a 1-3galactose covalent linking to the $\mathrm{O}$ structure resulting in the blood group B antigen sequence Gal a 13 [Fuc a 1-2] Gal $\beta$ - (Fig. 3) ${ }^{[24,25,32]}$. AB blood group individuals have both $\mathrm{A}$ and $\mathrm{B}$ glycosyltransferase, and both $\mathrm{A}$ and B glycan sequences ${ }^{[24,25,32]}$. Expression of the particular set of two specific types of glycosyltransferases, encoded in the single $\mathrm{ABO}$ gene, result in synthesis of the exact carbohydrate terminal sequences of blood group phenotype $\mathrm{A}, \mathrm{B} \mathrm{AB}$ or $\mathrm{O}$. The O blood group lacks both A and B glycosyltransferase, due to the presence of null alleles (encoding

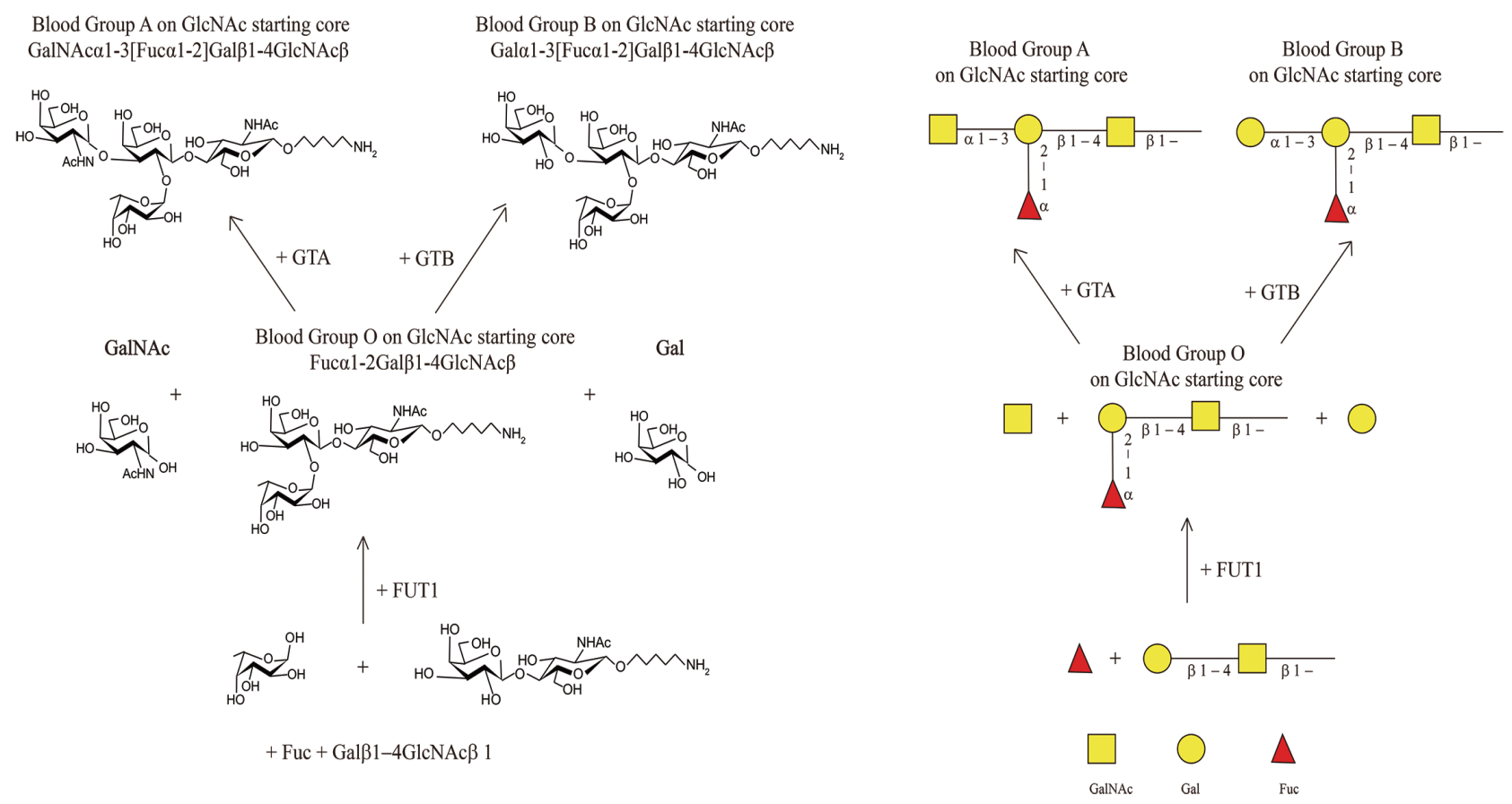

Fig. 3 Biosynthesis of ABO blood group antigen glycans. Biosynthesis pathway of ABO blood group antigen glycans is presented as in Fig. 1 in three different forms. FUT 1 : a -1,2-fucosyltransferases; GTA : a 1-3-N-acetylgalactosamyniltransferase or glycosyltransferase A; GTB: a 1-3-galactosyltranferase or glycosyltransferase; Gal: galactose; Fuc: fucose; GlcNAC : N-acetylglucosamine; GalNAc: N-acetylgalactosamin. 
nonfunctional transferase) so the resulting glycan antigen terminal sequence is classified as $\mathrm{O}^{[24,25,32]}$.

Since the ABO blood group terminal glycans reside on more complex linear or branch core polysaccharides linked either to protein or lipids, which are described here in the following sections, biosynthesis of the entire carrier structure is far more complex and being regulated by multiple enzymes which are encoded by many different genes.

\section{WHERE AND WHEN ARE ABO BLOOD GROUPS EXPRESSED?}

The location of the ABO blood group antigens expression has to be envisaged in two ways. The first one is determining which cell type and tissues expresses at which level glycosyltransferase messenger RNAs, glycosyltransferases proteins, and ABO blood group glycan antigens themselves. The second one is defining which protein and lipid biopolymer molecules carry these $\mathrm{ABO}$ carbohydrate antigen sequences, and at which number of copies they are present per cell. Quantitative knowledge about the ABO blood group antigens expression types and levels on each particular biopolymer and respective cell carrier type (in both donor and acceptor blood cell, plasma and tissues) are vital for predicting possible outcome scenarios in blood transfusion and transplantation. This knowledge is used as a guide for clinicians for choosing the most appropriate procedures for the patient.

Red blood cells express ABO carbohydrate sequences at a high level on their plasma membrane glycoproteins and glycolipids ${ }^{[2,15,44-51]}$. They are also present on epithelial and endothelial cell mucin polysaccharides and in fluids ${ }^{[2,15,44-51]}$. The ABO carbohydrate sequences are terminal structures on different types carbohydrate polymers, where remaining part backbone chains are different in terms of their primary sequence and branching degree, as well as the nature of the linkage to a carrier glycoprotein and lipid ${ }^{[2,15,44-51]}$. As the time of this review (June 2018) research reports indicated; 540 glycan structures containing blood group A sequence, 182 glycan structures containing blood group B sequence, and 2747 glycan structures containing blood group $\mathrm{O}$ were reported on https:// www.glytoucan.org ${ }^{[16]}$

On red blood cells the ABO terminal saccharide antigen sequences are presented as much as $75 \%$ of total antigens on $\mathrm{N}$-linked glycans, which resides on the major membrane glycoprotein Band $3^{[11,40,43-51]}$. The Band 3 has around one million copies per one red blood cell and carries about $50 \%$ of all ABO antigens ${ }^{[11,40,43-51]}$. Furthermore, detailed analyses of glycoproteins and glycolipids structures in red blood cells reavel that about $10 \% \mathrm{ABO}$ antigens reside on $\mathrm{O}$ linked glycans, and about $15 \%$ on the glycolipids ${ }^{[11,40,43-51]}$.

A large number of publications, as described above, showed that the $\mathrm{ABO}$ blood group antigens are terminal glycan sequences of either a linear or branch polysaccharide structure linked to a protein or a lipid ${ }^{[2-15,44-5]]}$. These polysaccharide structures are divided into four types designated with numbers 1 to 4 .

Type 1 core glycan structure is $X-G a l \beta 1-$ 3 GlcNAc $\beta 1-3 \mathrm{Gal} \beta 1-\mathrm{R}$, where $\mathrm{X}$ is either $\mathrm{A}$ or $\mathrm{B}$ or $\mathrm{O}$ sequence and $\mathrm{X}$ is any other structure linked to protein or ceramide ${ }^{[2-15,40,43-51]}$. This structure type is a minor carriers of $\mathrm{ABO}$ antigens in erythrocytes and is exclusively present on glycosphingolipids ${ }^{[11,40,43-51]}$. Galin $\mathrm{X}-\mathrm{Gal} \beta \mathrm{l}$ is the part of the $\mathrm{ABO}$ structure before the addition of fucose by FUT transferases. The synthesis of type 1 chain $\mathrm{O}$ antigen is dependent on the secretory FUT2 transferase, which is related a 1,2-FUT 1 fucosyltransferase. Individuals possessing secretorpositive Se locus also secrete type $1 \mathrm{ABO}$ antigens found in body fiuids such as plasma and saliva. Lung, skin, liver, pancreas, stomach, intestines, ovaries and prostate cells are producing and secreting mucins which carry $\mathrm{ABO}$ antigens $\mathrm{s}^{[40,43-51]}$.

Type 2 core structure is X-Gal $\beta 1-4$ GlcNAc $\beta$ 1$3 \mathrm{Gal} \beta$ l-R sequence being the major carrier of $\mathrm{ABO}$ antigens on red blood cells and also platelet and endothelium glycosphingolipids. This core sequence is also part of the larger polymeric form of $\mathrm{N}$-acetyllactosamine polysaccharides which are linked to the red blood cell membrane protein erythroglycan ${ }^{[11,40,43-51]}$. Interestingly, other tissues such as epithelia of gastrointestinal and genitourinary tract express small amount of type 2 core structures and large amount of type 1 core structures ${ }^{[11,40,43-51]}$. In terms of branching and polyvalence over 40 structural variants of type 2 polysaccharide sequences (having 4 to $6 \mathrm{ABO}$ antigens) have been reported. This clearly reflects the extreme complexity of $\mathrm{ABO}$ blood groups requiring multidisciplinary knowledge and approaches in connecting structural, chemical and biochemical analyses using mass spectrometry and nuclear magnetic resonance in combination with genetic, immunological and clinical studies ${ }^{[2-12,40,43-51]}$.

Type 3 core structure has two variants. The first one is glycosphingolipid X-Gal $\beta$ 1-3 GlcNAc a 13 Gal $\beta 1-4$ GlcNAc $\beta 1-3$ Gal $\beta 1-Y$, where $Y$ is the glycosphingolipid. The second one is mucin associated X-Gal $\beta$ 1-3GlcNAc a 1-Ser/Thr-Z, where $\mathrm{Z}$ is a mucin like protein ${ }^{[11,40,43-51]}$.Type 3 structure is related to the P Blood Group System and is present in small amounts in red cells with more residing in gastrointestinal tissue ${ }^{[40,43-51]}$. 
Type 4 core structure belongs to globo-series $\mathrm{X}-$ Gal $\beta$ 1-3GlcNAc $\beta$ 1-3Gal a 1-4Gal $\beta$ 1-Y, where Y is glucosylceramide or glycosphingolipid ${ }^{[1,, 40,43-51]}$.As per type 3 these type 4 structure is expressed in minor amounts in red blood cells and predominantly in gastrointestinal tissue ${ }^{[11,40,43-51]}$.

The ABO blood group antigens start to be expressed after the fifth week of development in red blood cells and in tissues and in the endothelial and epithelial cells of practically all developing organs and organ rudiments. In conclusion it has been found that $\mathrm{ABO}$ antigens are expressed on different types of glycan core structures which show developmental and tissue specificity.

\section{WHAT ARE BLOOD GROUPS ISOAN- TIBODIES AND WHEN THEY ARE EX- PRESSED?}

Isoantibodies, also referred as isohaemagglutinins, are anti-A, anti-B and anti-AB antibodies which develope during the first year of life ${ }^{[52-55]}$. The name isoantibody comes from the fact that they are raised by each individual against their own species antigens, termed isoantigens. Biosynthesis of naturally occurring isoantibodies against blood group antigens $\mathrm{A}$ and $\mathrm{B}$ is induced as a response to either intestinal bacterial infection, viral infections and or plantfood ${ }^{[52-55]}$. Isoantibodies are detected approximately 4 to 6 month after birth. Between 5 and 10 years of age their concentration raises to normally occurring levels ${ }^{[52-55]}$. Diets contain always different kinds of bacteria. This results in the formation of gastrointestinal microbiomes. Several bacterial species express glycan structures on lipopolysaccharide that are similar to $\mathrm{ABO}$ antigensand cross-react with anti-ABO antibodies $^{[52-55]}$. In individuals with blood group A will induce immune reaction against blood group B antigens present on bacteria and develop tolerance to self-antigen of blood group A also present on bacteria. Individuals with blood group B will develop anti-A and tolerates self-B antigen. AB individuals will not make antibodies against $\mathrm{A}$ and $\mathrm{B}$ self-glycan antigens whereas blood group $\mathrm{O}$ carriers will develop both anti-A and $\mathrm{B}$ isoantibodies.

Biological roles for $\mathrm{ABO}$ blood group antigens have been postulated in cancer, immunity to infectious diseases and coagulation ${ }^{[56-67]}$. However, the functions of $\mathrm{ABO}$ blood group glycans are not actually known. The ABO terminal glycan structures are present to different degreesin diverse tissues (in both healthy and diseased conditions) and they can 1) bind to lectins, and 2)change three dimensional structure of cell sur- face or fluid carrier glycoproteins. It is therefore, very likely that these type of glycansare to be directly or indirectly involved in variety of cell to cell and cell to extracellular matrix interactions, as well as intermolecular binding among body fluid glycoproteins and glycolipids as shown for other specific carbohydrate structure ${ }^{[68-69]}$.It is without dispute that the future multidisciplinary approaches connecting fundamental and clinical research will better aid understanding of the functional role of $\mathrm{ABO}$ glycan structures. This will likely advance our today's knowledge,which is mainly based on correlation type of studies, to a more advance state of structure to function related research capable of providing causal relationships and molecular mechanism in healthy and disease conditions.

As described in the section of isoantibodies, bacterial, viral and plant antigens have epitopes similar to $\mathrm{A}$ and $\mathrm{B}$ glycan structures that can induce the immune system to produce isoantibodies against non-selfblood group antigen. For example, anti-A antibodies could originate from immune responses against the influenza virus, which carry similar structures to the A blood group. One suggested explanation is that viruses acquire cell membranes which carry $\mathrm{ABO}$ blood antigens from the infected mucosal epithelium of a human host and transmit them into newly infected individuals. In case where new born individuals have a different blood group,an immune response against these non-self antigens will be induced. Anti-B and antiA isoantibodies could be result of immune response against gram-negative bacteria, which have similar structures to blood group B antigen ${ }^{[2-15,52-53]}$. Answering the question as to how and why $\mathrm{ABO}$ blood group antigens and isoantibodies have emerged, an evolutionary hypothesis suggests the cause to be; are duction infections' inter-transmissibility within a population with a higher diversity of antigenic structures.

As described above, a large number of clinical correlation studies were performed together with in vitro experimentation revealing the role of $\mathrm{ABO}$ glycan antigens in cancer, immunity and coagulation. For example, several reports were published showing that survival prognoses for patients with various tumor types and the prevalence for acquiring various type of tumors,both correlate with the degree and the type of ABO blood group antigens expression ${ }^{[56-65]}$. Although, the exact mechanisms have not revealed clear associations have been found with inflammation, immunity and apoptosis regulatory process ${ }^{[56-69]}$. For example, the lowered expression of A and B antigens in different types of cancer, such as lung, esophageal, and bladder,is accompanies a worse prognosis ${ }^{[56-69]}$. Separate studies revealed that the overexpression of $\mathrm{O}$ 
antigen, due to increased $\mathrm{FUCl}$ glycosyltransferasecatalytic activity, is also related with poor prognosis in colon cancer ${ }^{[63]}$. In addition, in vitro cell culture studies with tumor cell lines revealed the correlation between either low expression or absence of an A and B structures, with an increase in induced cellular motility ${ }^{[60]}$. These have been explained in the above paragraph, by the argument that conformational changes induced by the glycosylation pattern which alters integrin molecules' adhesion and signaling functions ${ }^{[60-61]}$. Interestingly, it has been reported that competition between sialyltransferase and A and B glycosyltransferases for the same core glycan structure may lead to the modulation of the glycosylation patterns and the emergence of new glycan structures on many adhesion and other membrane molecules. One of the outcome scenarios is the increase of sialic acid binding sites for lectin cell adhesion molecules resulting (similarly as in the case of integrins) in changes in cellular adhesion and motility properties which are tightly connected with tumorigenicity, metastasis and survival rates of patients ${ }^{[62]}$.

Correlations were also found between $\mathrm{ABO}$ blood groups and coagulation. For example, blood group $\mathrm{O}$ individuals have the lowest risk of thrombosis ${ }^{[6]}$.

In infectious diseases correlation was discovered between susceptibility for malaria. Namely, blood group $\mathrm{O}$ individual have better chances of survival ${ }^{[67,70-71]}$. The association of ABO blood group antigens with immunity against bacterial infections was reported by in vitro experiments showing that anti-B isoantibodies bind and induce the cascade of complement driven reactions against bacteria expressing lipopolysaccharides similar to B terminal glycan which finallyleads to phagocytosis ${ }^{[67,70-71]}$. Indeed, clinical studies revealed that individual without isoantibodies against $B$ antigen are more susceptible to E. coli and Salmonella infections ${ }^{[72-73]}$. In the case of infections with enveloped viruses, such as HIV and the SARS-CoV similar correlations were found ${ }^{[70]}$. Specifically, individuals with the O blood group were more resistant ${ }^{[74-75]}$.

\section{HEMOLYTIC DISEASE OF THE FETUS AND NEWBORN}

ABO incompatibility between the mother and fetus is of great concern due to the possible occurrence of hemolytic disease of the fetus or newborn. This may happen in the case of mother having $\mathrm{O}$ type blood (genotype is $\mathrm{OO}$ ) and child having either the A (genotype $\mathrm{AO}$ ), or $\mathrm{B}$ (genotype $\mathrm{BO}$ ) blood type. The reaction can range from the mild to the extreme in some cases leading to the death. Today's understanding of blood type incompatibility between mother and fetus is based on the facts that: 1) anti-A and anti-B isoantibodies are IgM in nature and cannot pass through placenta from mother to fetuses' blood; 2) in rare cases, some $\mathrm{O}$ type individuals produce anti-B and anti-A $\operatorname{IgG}$ isoantibodies that may pass the placenta which can induce a hemolytic reaction; 3 ) in rare cases mothers with blood group A can produce anti-B IgG antibodies that can pass through placenta; 4 ) a fetuses' red blood cells have less A or B antigen expressed than in later life $\mathrm{e}^{[52-55,76-79]}$. The important question is why $\mathrm{O}$ type blood group mothers develop anti-A and anti-B IgG antibodies. The possible causes are: 1) environmental exposure; 2)fetal-maternal transfusion; 3) incompatible blood transfusion ${ }^{[52-55,76-79]}$.

Hemolytic disease of the fetus and newborn diagnosis can be performed by routine blood analyses.

\section{TRANSFUSION AND TRANSPLANTA- TION DONOR RECIPIENT COMPAT- IBILITIES}

Anti-A isoantibodies are present in blood group B and $\mathrm{O}$ individual,anti-B isoantibodies are present in blood group $\mathrm{A}$ and $\mathrm{O}$ individuals, andboth anti-A and anti-B isoantibodies are present in blood group $\mathrm{O}$ individuals, anti-A and anti-B isoantibodies are absent in blood group $\mathrm{AB}$ individuals, and the anti-O isoantibodies are absent in all $\mathrm{ABO}$ blood group individuals with the exceptions of Bombay blood group individuals ${ }^{[52-55,80]}$. The isoantibodies against $\mathrm{A}$ and $\mathrm{B}$ antigens are IgM type(Fig. 4). The above presented facts are used for establishing principal rules in theclinical practice of blood transfusion and transplantation. Incompatibility between blood groups of donor and recipient will cause intravascular hemolysis by fixing complement and rejection of the transplant with likely rapid death outcome ${ }^{[52]}$.

Blood group A individuals can receive whole blood or their products from donors of blood group type A and red blood cells from blood group type $\mathrm{O}$; blood group B individuals can receive whole blood or their products from donors of blood group type $B$ and red blood cells from blood group type $\mathrm{O}$, blood group $\mathrm{AB}$ individuals can receive whole blood or their products from donors of blood group type $\mathrm{AB}$, and red blood cells from blood group type from $\mathrm{A}, \mathrm{B}$ and $\mathrm{O}$; and blood group $\mathrm{O}$ individuals can receive blood from donors of only blood group type $\mathrm{O}^{[80]}$. For example, if blood group $\mathrm{O}$ individuals, who have anti-A and anti$B$ isoantibodies in the serum, transfuse whole blood to an $\mathrm{A}, \mathrm{B}$, or $\mathrm{AB}$ recipient, who has $\mathrm{A}, \mathrm{B}$, and $\mathrm{AB}$ antigen respectively, a hemolytic reaction will occur.

The blood transfusion is actually a category of liquid organ transplantation. The solid organ trans- 

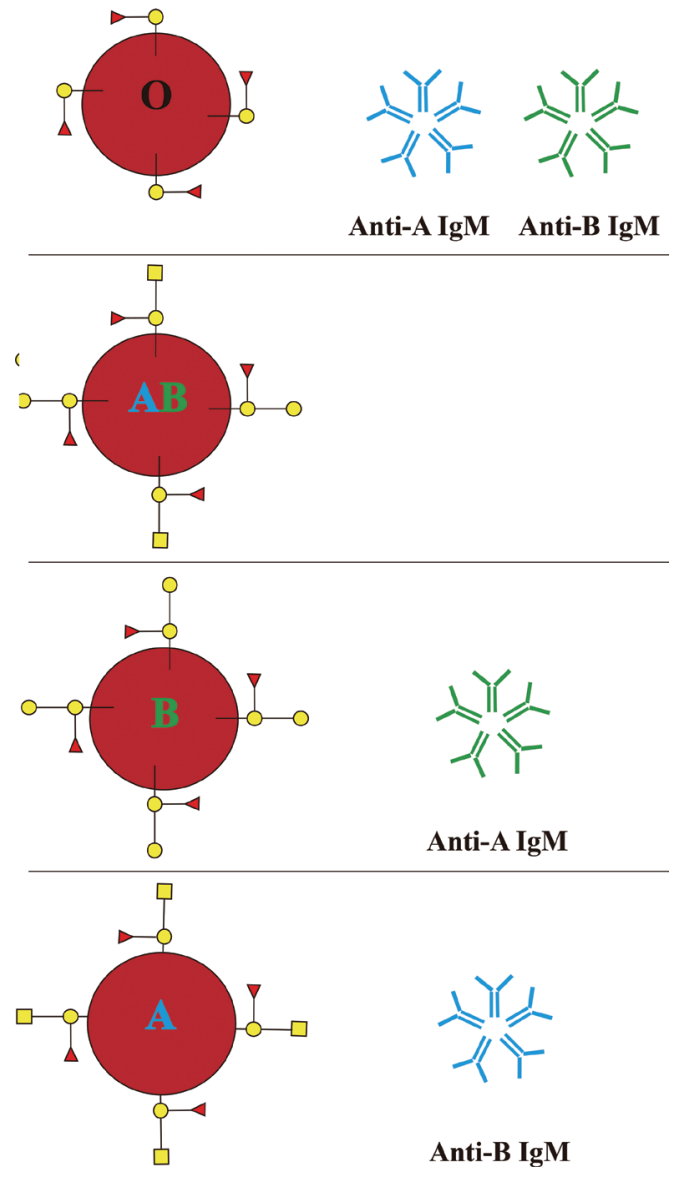

Fig. 4 Schematic presentation of $\mathrm{ABO}$ blood group antigens and isoantibodies. Red blood cells with $\mathrm{A}, \mathrm{B}, \mathrm{AB}$ and $\mathrm{O}$ glycan antigens and anti- $\mathrm{A}$ and anti-B IgM isoantibodies are schematically presented as in Fig 1 in order to illustrate immunologically relevant components of different blood groups important for choosing compatible transfusion.

plantation category would, therefore, includes all of the solid organs transplantations. Since practically all of the nucleated cells in adult humans express one of the four ABO blood phenotypes(which are genetically determined) every solid organ transplantation should, as in transfusion, involve precise selection of matched ABO blood groups between donor and recipient. Reports of $\mathrm{ABO}$ incompatible organ transplants done in early transplantation trials or in emergency cases for several type of organs are only very rarely success$\mathrm{ful}^{[81]}$. Commonly most of the cases of such transplantation end in the acute or hyperacute rejection of $\mathrm{A}$ and/or B blood group antigens (present on epithelial and endothelial cell) due to the presence of host B cells producing isoantibodies against non-matched ABO blood antigen.

In medical reports covering $\mathrm{ABO}$ incompatible transplantations infants and neonates have shown that during the non-mature immunity stage some success can be achieved without involving immune suppres- sion by drug treatment or splenectomy ${ }^{[81-82]}$.

Human stem cell transplantation reports reveal that the donor and recipient most incompatible for $\mathrm{ABO}$ blood group lead to hemolytic reactions ${ }^{[81-82]}$. Similarly, for whole bone marrow transplantation with incompatible ABO blood group results are not better, although there is difference in the time response engraftments of red blood cells and lymphocytes and in immune reactions associated with host versus graft or vice versa graft versus host ${ }^{[33-84]}$.

Due to possible typographic errors in printing or electronic publishing, it is essential that all data presented in tables and text should be verified before any practical usage via official clinical manuals issued by the official transfusion societies.

\section{ABO BLOOD GROUPS ANALYSES AP- PROCHES}

For the complete analyses of $\mathrm{ABO}$ blood types,four approaches involving different methodologies have to be applied: 1) genetic analyses covering complete ABO gene sequencing; 2) molecular biology measurements of $\mathrm{ABO}$ gene RNA transcripts expression; 3 ) glycobiology related analytics for measuring the expression levels of ABO carbohydrate antigens themselves on different cell types, on different carrier proteins and on core carbohydrate sequences on which they are terminated structures; 4) immunological measurements of quantities of the all isoantibody types, their affinities as well as the presence of memory and progenitor B and T cells. Unfortunately, these proposed complete analyses are impossible at the present time to be entirely applied in the clinical praxis due to complexity of methodologies used for each particular type of analysis, to the high level of required multidisciplinary expertise, to the multiple complex instrumentations required, and finally due to the long necessary time for obtaining results as well as for the very high cost.

In clinical praxis, serological analyses are commonly used for the phenotypic determination of $\mathrm{ABO}$ blood groups in red blood cells, for the measurements of isoantibodies in the serum, and for determinationof isoantibodies' class and subclass types. A common approach is the use of indirect Coombs test, also known as the indirect antiglobulin test. This assay measures in vitro antibody-antigen reactionsin order to quantitatively determine blood group phenotype and the presence of anti-ABO blood group isoantibodies in donor and in recipient blood ${ }^{[85]}$. For such measurement,blood sample from the recipient and donor are both screened for the presence of anti-A, B and $\mathrm{AB}$ isoantibodies by incubating with red blood cells of 
$\mathrm{A}, \mathrm{B}, \mathrm{AB}$ and $\mathrm{O}$ blood phenotype. One of the emerging methods is the card chromatography like gel cassette system: which offers the fast, reliable and simple determinationof isoantibodies class and subclass.

\section{BRIEF HISTORY OF ABO BLOOD GROUP SYSTEM AND GLYCOSYL TARNSFERASE DISCOVERY}

The scientific history about ABO blood groups starts in 1990 with discovery of three blood types A, $\mathrm{B}$, and $\mathrm{O}$ by Karl Landsteiner ${ }^{[86]}$. Interestingly Jansky ${ }^{[87]}$, as well as Moss both independently found blood groups types in humans, however, they used different classification method ${ }^{[88]}$. In 1902 Decastrello and Sturli discovered the fourth type, $\mathrm{AB}^{\left[{ }^{[9]} \text {. }\right.}$ Followed were genetic studies about inheritance patterns, which showed multiple allele controlling $\mathrm{ABO}$ phenotypes at a single locus ${ }^{[90]}$. Finally, the chemical structure was revealed by the pioneering work of Watkins and Morgan showing that structure of blood groups belong to specific carbohydrate sequences, namely that $\mathrm{N}$-acetylgalactosamine is specific for the $\mathrm{A}$ and galactose for the $\mathrm{B}$ blood type ${ }^{[2]}$. More recent studies revealed that the glycan structures of blood groups are terminal saccharide sequences expressed on glycolipids and glycoproteins ${ }^{[3-15]}$. At last, with the use of molecular biology tools, gene cloning and sequencing of specific glycosyltransferase genes (which encode the enzymes catalyzing the biosynthesis of blood group carbohydrate antigens) were revealed with initial work of Yamamoto's research group ${ }^{[7]}$. Using NMR, $x$-ray crystallography and modeling approaches, three dimensional structures of glycosyltransferases and blood group antigens were revealed $^{[91-97]}$. For example, 103 different reports exist about the three dimensional structure of transferase A, alpha 1-3-N-acetylgalactosaminyltransferase ${ }^{[92]}$, and for transferase B, alpha 1-3-galactosytransferase 159 reports about $3 \mathrm{D}$ structures have already been published ${ }^{[95-97]}$ (Fig. 5)

\section{IMPORTANCE AND FUTURE PERSPEC- TIVES OF ABO BLOOD GROUPS}

Knowledge concerning the ABO blood group system is primarily important in the clinical practice of blood transfusion, transplantation, cellular or molecular therapies, new born hemolytic diseases and in the application for emerging personalized medicine approaches in diagnosis and therapy. In order to improve precision, sensitivity, effectiveness and to achieve complete $\mathrm{ABO}$ analyses from the gene sequencing, via transcription to carbohydrate expression levels further advancement are required in; 1) the unification
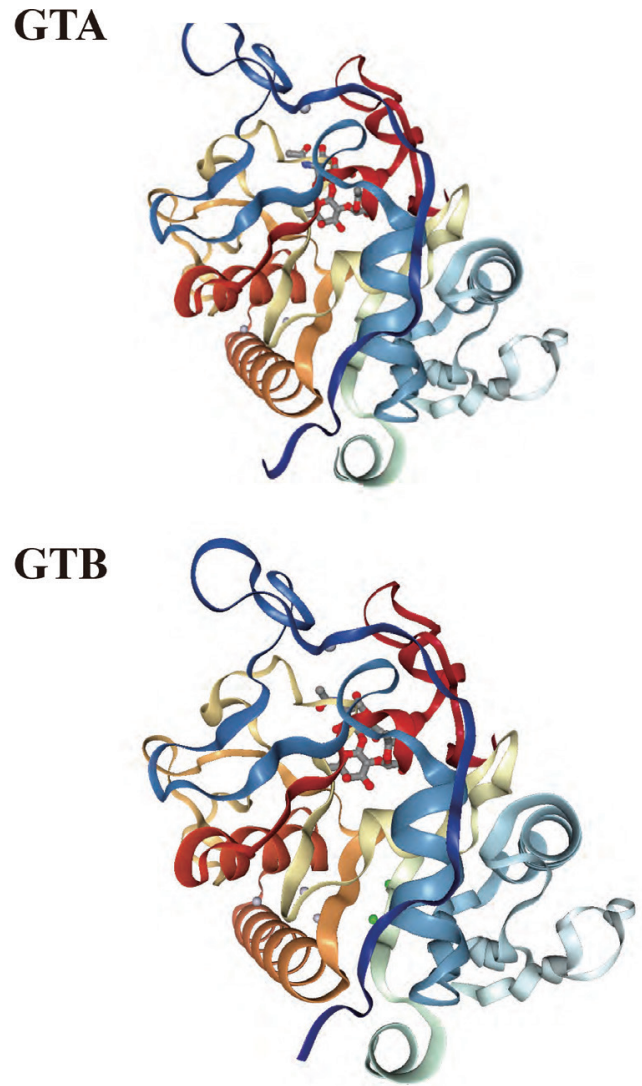

Fig. 5 Three dimensional structure of ABO glycosyltransferase A and B. X-ray diffraction analyses of crystal structure of human GTA complexed with O blood type II trisaccharide, and GTB complexed with O blood type II trisaccharide. 3D Images links:http://www.rcsb.org/structure/1ZHJ; http://www.rcsb.org/structure/1ZJ3

and standardization of analytical methods, 2) instrumentation and 3) data bank information services. This will involve development of novel analytical nano technologies and their bridging with current micro technologies. Some successful attempts have been made in construction of prototypes of nano in micro array "omic" chips for the sampling of over 2000 single cells, each individually positioned in a separate micro well with 20 micrometers in diameter, on

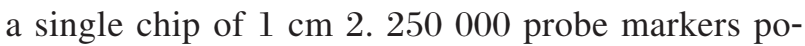
sitioned in each nanowell of 20 nanometers diameter (located in each micro well) allows complete and high throughput "omic"analyses ${ }^{[98]}$. The second nano approach is based on high throughput open guides nano electrophoresis array prototypes for separation type of "omic" analyses. This chips can accommodate 100 different cell samplings per $1 \mathrm{~cm}^{2[98]}$. These novel approaches are combined with ultra-sensitive single molecule detection and quantification using Secondary Ion Mass Spectrometry ${ }^{[99]}$.Combined nano and micro approaches are superior to commonly used microfluidics, capillary electrophoresis and micro-arrays 
using mass spectrometry and fluorescent labeling for molecular detection. These developments are essential seeds for progressing towards faster, simpler and more sensitive clinically applicable methods, capable of detecting and quantifying single antigen and antibody molecules. Eminently as a result we shall expect the extension of our basic and clinical knowledge.

Future goalsin the multidisciplinary studies of the ABO blood group system is to connect structure to function related research by analyzing more extensively: 1) the diversity and complexity of the core glycan structure which carries terminal ABO carbohydrate sequences, as well as their glycoprotein and glycolipid carrier in healthy and disease state; 2) the spatial and temporal distribution of ABO blood group antigens and A and B glycosyltransferases in cells tissues and organs during development and in adult life in both healthy and disease states; 3) the diversity of $\mathrm{ABO}$ gene alleles and their geographical distribution, $\mathrm{ABO}$ gene transcriptional control and enzymatic activity of A and B glycosyltransferases; 4) the association of $\mathrm{ABO}$ genes and $\mathrm{ABO}$ phenotypes with infectious, cancer and other diseases; 5) potential functions of $\mathrm{ABO}$ glycan antigens in a variety of in vivo and in vitro assays, such as glycan to glycan binding which goes beyond classical examples of well-known protein to glycan, protein to protein, protein to DNA or RNA, DNA to DNA, DNA to RNA and DNA to RNA ${ }^{[68-69,100-104]}$.

\section{CONCLUDING SUMMARY}

The ABO blood group system in humans has three different carbohydrate antigens named A, B, and $\mathrm{O}$. Each individual expresses either A, or B, or A plus $\mathrm{B}$, or $\mathrm{O}$ antigen resulting in four blood groups phenotypes termed $\mathrm{A}, \mathrm{B}, \mathrm{AB}$ and $\mathrm{O}$. The $\mathrm{A}, \mathrm{B}$ and $\mathrm{O}$ structures are termination glycan sequences on variety of complex carbohydrates residing on different glycoproteins and glycolipids which are located on plasma membrane of red blood cells and almost all nucleated cell types. The A antigen sequence is terminal trisaccharide GalNAc a 1-3[Fuc a 1-2]Gal $\beta$-, B is terminal trisaccharide Gal a $1-3$ [Fuc a 1-2]Gal $\beta$-, and $O$ is terminal disaccharide Fuc a $1-2 \mathrm{Gal} \beta-$ and is a biosynthetic precursor of A and B antigens. According to the classification of the International Society of Blood Transfusion, the ABO group is one of the 36 blood group systems known in humans.

Since ABO blood groups are glycans, their sequences and their structures are not directly encoded in genes as in proteins. The expression of particular sets of genes encoding specific types of glycosyltransferases (which are catalyzing biosynthesis of glycans) result in the exact carbohydrate sequences. In humans, the single $\mathrm{ABO}$ gene locus has three alleles types A, B and O. A and B genes code A and B glycosyltransferases respectively and $\mathrm{O}$ encodes an inactive enzyme. The A-glycosyltransferase catalyzes GalNAc transfer to the $\mathrm{O}$ structure resulting in the blood group A antigen sequence. The B-glycosyltransferase catalyzes $\mathrm{Gal}$ transfer to the $\mathrm{O}$ structure resulting in blood group $B$ antigen sequence. $A B$ blood group individuals have both A and B glycosyltransferase and both A and B glycan sequences. The O blood group has no glycosyltransferase activity leaving the precursor $\mathrm{O}$ glycan antigen terminal sequence unmodified. A large allelic diversity has been found for A and B transferases resulting in the genetic subgrouping of each $\mathrm{ABO}$ blood type. Genes for both transferases have been cloned and the 3D structure of enzymes with and without substrate has been revealed by NMR and X ray crystallography. The FUT 1 and 2 genes which encode the a-1,2-fucosyltransferases responsible for the biosynthesis of $\mathrm{O}$ sequence(also termed as $\mathrm{H}$ antigen), have also been sequenced and cloned.

The core polysaccharide structures which carry terminal blood group antigen are very diverse in terms of primary sequence, branching properties and valence. These, together with the fact that similar polysaccharides are found in bacteria, viruses and plants indicates many possible biological roles, some of which have been examined in correlation type of studies related to immunity, cancer, infectious diseases and physiological processes linked to health and diseased states. However, the exact function of ABO blood group antigens remains unknown.

The ABO blood group system plays a vital role in transfusion, organ and tissue transplantation, as well as in cellular or molecular therapies. If a deference in ABO blood groups exists between blood or transplant donor and receiver,such receiver individuals are liable to exhibit immune reactions with life threatening consequences due to the presence of isoantibodies against non-self-blood group.

The current multidisciplinary knowledge about ABO blood group system (as of June 2018), which is summarized above, together with historical aspects and future perspectives will be covered in this review articl. The current multidisciplinary knowledge about the ABO blood group system (as of June 2018), summarized above will be covered in this review article together with historical aspects and future perspectives.

\section{Acknowledgments}

This work was supported in part by University of 
Brest, France, by Gimmune GmbH Zug, Switzerland and by private GNM funds.

\section{References}

[1] http://www.isbtweb.org/fileadmin/user_upload/Working_parties/WP_on_Red_Cell_Immunogenetics_and/ Updates/Table_of_blood_group_systems_v5.1_180207. pdf[Z]. [2018-05-18]

[2] Morgan WTJ,Watkins WM. Genetic and biochemical aspects of human blood-group A-, B-, H-, Lea- and Lebspecificity[J]. Br Med Bull,1969, 25: 30-34.

[3] Watkins WM. Biochemistry and genetics of the ABO, Lewis, and $\mathrm{P}$ blood group systems, advances in human genetics (Eds, Harris H, Hirschhorn K.) [M]. New York: Plenum Publishing Corporation, 1980: 10 1-136

[4] Watkins WM, Morgan WTJ, Watkins WM, et al. Possible genetical pathways for the biosynthesis of blood group mucopolysaccharides[J]. Vox Sang, 1959, 4(2): 97-119.

[5] Järnefelt J, Rush J, Li YT, et al. a high molecular weight glycopeptide with the repeating structure [galactosyl-(1 leads to 4)-2-deoxy-2-acetamido-glucosyl-(1 leads to $3)$ ] comprising more than one-third of the protein-bound carbohydrate of human erythrocyte stroma[J]. J Biol Chem,1978, 253: 8006-8009.

[6] LaineRA, Rush J. Chemistry of human erythrocyte polylactosamine glycopeptides (erythroglycans) as related to $\mathrm{ABH}$ blood group anitgenic determinants, molecular immunology of complex carbohydrates[M]. New York: Plenum Publishing Corporation,1988: 331

[7] Yamamoto F, Clausen H, White T, et al. Molecular genetic basis of the histo-blood group ABO system[J]. Nature, 1990, 345: 229-233.

[8] Yamamoto F. Review: ABO blood group system--ABH oligosaccharide antigens, anti- $\mathrm{A}$ and anti-B, $\mathrm{A}$ and $\mathrm{B}$ glycosyltransferases, and $\mathrm{ABO}$ genes[J]. Immunohematology,2004,20(1):3-22

[9] Clausen H, Hakomori S. ABH and related histo-blood group antigens: Immunochemical differences in carrier isotypes and their distribution[J]. Vox Sang, 1989, 56: $1-20$.

[10] Hakomori S, Stellner K, Watanabe K. Four antigenic variants of blood group A glycolipid: examples of highly complex, branched chain glycolipid of animal cell membrane[J]. Biochem Biophys Res Commun, 1972,49(4):1061-1068

[11] Wilczynska Z, Miller-Podraza H, Koscielak J. The contribution of different glycoconjugates to the total $\mathrm{ABH}$ blood group activity of human erythrocytes[J]. FEBS Lett, 1980, 112:277-279.

[12] Zdebska E, Krauze R, Koscielak J. Structure and bloodgroup I activity of poly (glycosyl)-ceramides[J]. Carbohydr Res, 1983, 120: 113-120.

[13] Fukuda M, Dell A, Oates JE, et al. Structure of branched lactosaminoglycan, the carbohydrate moiety of band 3 isolated from adult human erythrocytes[J].J Biol Chem, 1984, 259(13):8260-8273
[14] Finne J, Krusius T, Rauvala H, et al. Alkali-stable blood group A- and B-active poly(glycosyl)-peptides from human erythrocyte membrane[J]. FEBS Lett,1978,89(1):111-115

[15] KrusiusT, Finne J, Rauvala H. The Poly(glycosyl) chains of glycoproteins. characterisation of a novel type of glycoprotein saccharides from human erythrocyte membrane[J]. Eur J Biochem, 1978, 92: 289-300.

[16] https://www.glytoucan.org/ Retrieved 18.05.2018[Z]. [2018-05-18]

[17] http://www.unicarbkb.org/ Retrieved 18.05.2018[Z]. [2018-05-18]

[18] https://pubchem.ncbi.nlm.nih.gov/ Retrieved 18.05.2018[Z]. [2018-05-18]

[19] http://www.genome.jp/ Retrieved 18.05.2018[Z]. [201805-18]

[20] http://www.genome.jp/dbget-bin/www_bfind_sub? mode $=$ bfind\&max_hit $=1000 \& d b k e y=$ glycan\&keywords [Z]. [2018-05-18]

[21] https://www.ncbi.nlm.nih.gov/gene? $\mathrm{Db}=$ gene $\& \mathrm{Cmd}=\mathrm{Sh}$ owDetailView\&TermToSearch=28[Z].[2018-02-05]

[22] https://www.genenames.org/cgi-bin/gene_symbol_ report?hgnc_id=HGNC:79[Z].[2018-02-05]

[23] Ferguson-Smith MA, Aitken DA, Turleau C, et al. Localisation of the human ABO: Np-1: AK-1 linkage group by regional assignment of AK-1 to 9q34[J]. Hum Genet,1976,34(1):35-43

[24] Yamamoto F, Marken J, Tsuji T, et al. Cloning and characterization of DNA complementary to human UDP-GalNAc:Fuc alpha 1--2Gal alpha 1--3GalNAc transferase (histo-blood group A transferase) mRNA[J]. J Biol Chem,1990, 265: 1146-1151.

[25] Yamamoto F, Mcneill PD, Hakomori S. Human histoblood group A2 transferase coded by A2 allele, one of the A subtypes, is characterized by a single base deletion in the coding sequence, which results in an additional domain at the carboxyl terminal[J]. Biochem Biophys Res Coтmun,1992,187(1):366-374

[26] Yamamoto F, McNeill PD, Kominato Y, et al. Molecular genetic analysis of the $\mathrm{ABO}$ blood group system. cis- $\mathrm{AB}$ alleles 2[J]. Vox Sang, 1993, 64:120-123.

[27] Yamamoto F, McNeill PD, Hakomori S. Genomic organization of human histo-blood group ABO genes[J]. Glycobiology, 1995, 5: 51-58.

[28] Amundadottir L, Kraft P, Stolzenberg-Solomon RZ, et al. Genome-wide association study identifies variants in the ABO locus associated with susceptibility to pancreatic cancer[J]. 2009, Nature Genet, 41: 986-990.

[29] https://www.genenames.org/about/faq/\#whatisthehgnc Retrieved[Z].[2018-05-23]

[30] Hakomori S. Antigen structure and genetic basis of histoblood groups A, B and O: their changes associated with human cancer[J]. Biochimica et Biophysica Acta, 1999, 1473: 247-266.

[31] MondJJ,LeesA,SnapperCM. Tcell-independenttype2[J]. Ann Rev Immunol, 1995,13: 655-659.

[32] Blumenfeld OO. The ABO gene-more variation! (Letter) 
[J]. Blood, 2003, 102: 2715

[33] Larsen RD, Ernst LK, Nair RP, et al. Molecular cloning, sequence, and expression of a human GDP-Lfucose:beta-D-galactoside 2-alpha-L-fucosyltransferase cDNA that can form the $\mathrm{H}$ blood group antigen[J]. Proc Natl Acad Sci U S A,1990, 87(17):6674-6678.

[34] Reed R, Maniatis T. A role for exon sequences and splicesite proximity in splice-site selection[J]. Cell,1986, 46:681-690.

[35] Bennett EP, Steffensen R, ClausenH ,et al. Genomic cloning of the human histo-blood group ABO locus[J]. Biochem Biophys Res Commun, 1995, 206:318-325.

[36] https://genome.ucsc.edu/cgi-bin/hgTracks?db=hg38\&la stVirtModeType $=$ default \&lastVirtModeExtraState $=\&$ virtModeType $=$ default $\&$ virtMode $=0 \&$ nonVirtPosition $=\&$ position $=\mathrm{chr} 19 \% 3 \mathrm{~A} 48748010 \% 2 \mathrm{D} 48755389 \& \mathrm{hg}-$ sid=673694045_c6jkrlbzvFmpIYca7IbZaUwfwIN3 8[Z].[2018-05-25]

[37] Larsen RD, Ernst LK, Nair RP, et al. Molecular cloning, sequence, and expression of a human GDP-Lfucose:beta-D-galactoside 2-alpha-L-fucosyltransferase cDNA that can form the $\mathrm{H}$ blood group antigen[J]. Proc Nat Acad Sci,1990, 87: 6674-6678.

[38] Rouquier S, Lowe JB, Kelly RJ, et al. Molecular cloning of a human genomic region containing the $\mathrm{H}$ blood group alpha-(1,2)fucosyltransferase gene and two $\mathrm{H}$ locus-related DNA restriction fragments: isolation of a candidate for the human secretor blood group locus[J]. $J$ Biol Chem,1995, 270: 4632-4639.

[39] https://genome.ucsc.edu/cgi-bin/hgTracks?db=hg38\&la stVirtModeType $=$ default\&lastVirtModeExtraState $=\&$ virtModeType $=$ default $\&$ virtMode $=0 \&$ nonVirtPosition $=\&$ position $=\mathrm{chr} 19 \% 3 \mathrm{~A} 48695970 \% 2 \mathrm{D} 48705933 \& \mathrm{hg}-$ sid=673700609_rqBtF1Xd08Q117rT9otrhpV0MwSA[Z]. [2018-05-25].

[40] Hazra A, Kraft P, Selhub J, et al. Common variants of FUT2 are associated with plasma vitamin B12 levels[J]. Nat Genet, 2008, 40(10):1160-1162.

[41] BretonC,SnajdrovaL,JeanneauC,et al. Structures and mechanisms of glycosyltransferases[J]. Glycobiology, 2006,16: 29937.

[42] Brockhausen I. Crossroads between bacterial and mammalian glycosyltransferases[J]. Front Immunology, 2014, 5: -4921

[43] Kelly RJ, Ernst LK, Larsen RD, et al. Molecular basis for $\mathrm{H}$ blood group deficiency in Bombay $(\mathrm{Oh})$ and paraBombay individuals[J]. Proc Nat Acad Sci,1994, 91: 5843-5847.

[44] Ravn V, Dabelsteen E. Tissue distribution of histo-blood group antigens[J]. APMIS, 2000, 108: 1-28.

[45] Wada H, Suda T, Miura Y, et al. Expression of major blood group antigens on human erythroid cells in a two phase liquid culture system[J]. Blood, 1990, 75:505-511.

[46] Mölne J, Björquist P, Andersson K, et al. Blood group $\mathrm{ABO}$ antigen expression in human embryonic stem cells and in differentiated hepatocyte- and cardiomyocyte-like cells[J]. Transplantation, 2008, 86 :1407-1413.
[47] Cao Y, Merling A, Karsten U, et al. The fucosylated histo-blood group antigens $\mathrm{H}$ type 2 (blood group $\mathrm{O}, \mathrm{CD} 173)$ and Lewis Y (CD174) are expressed on CD34+ hematopoietic progenitors but absent on mature lymphocytes[J]. Glycobiology, 2001, 11:677-683.

[48] Szulman AE. Evolution of ABO blood group antigens during embryogenesis[J]. Ann Inst Pasteur/Immunol, 1987, 138: 845-847.

[49] Hakomori S. Blood group ABH and Ii antigens of human erythrocytes: Chemistry, polymorphism and their developmental change[J]. Semin Hematol, 1981, 18: 39-62.

[50] Fukuda M, Fukuda MN, Papayannopoulou T, et al. Membrane differentiation in human erythroid cells: Unique pro $\varnothing$ les of cell surface glycoproteins expressed in erythroblasts in vitro from three ontogenic stages[J]. Proc Natl Acad Sci USA, 1980, 77: 3474-3478.

[51] Finne J. Identification of the blood-group ABH-active glycoprotein components of human erythrocyte membrane[J]. Eur J Biochem, 1980, 104: 181-189.

[52] Fung MK, Grossman BJ, Hillyer CD, et al. Technical manual[M]. 19th ed. Bethesda, MD: AABB Press, 2014.

[53] Springer GF. Blood-group and Forssman antigenic determinant shared between microbes and mammalian cells[J]. Prog Allergy, 1971, 15:9-77.

[54] Springer GF, Horton RE Forbes M. Origin of antihuman blood group B agglutinins in white leghorn chicks[J]. J Exp Med,1959, 110:221-224.

[55] Springer GF, Horton RE. Blood group isoantibody stimulation in man by feeding blood group-active bacteria[J]. J Clin Invest, 1969, 48: 1280-1291.

[56] Yang X,Huang Y,Feng JF. Is there an association between $\mathrm{ABO}$ blood group and overall survival in patients with esophageal squamous cell carcinoma? [J]. Int $J$ Clin Exp Med, 2014, 7:2214-2218.

[57] Suadicani P, Hein HO, Gyntelberg F. ABO phenotypes and infiammation-related predicators of lung cancer mortality: the Copenhagen male study-a 16-year followup[J]. Eur Respir J, 2007, 30:13-20.

[58] Lee JS, Ro JY, Sahin AA, et al. Expression of blood group antigen A: a favorable prognostic factor in nonsmall-cell lung cancer[J]. N Engl J Med, 1991,324:10841090.

[59] LePendu, Marionneau S, Cailleau-Thomas A, et al. ABH and Lewis histo-blood group antigens in cancer[J]. $A P$ MIS, 2001, 109:9-31.

[60] Ichikawa D, Handa K, Withers DA, et al. Histo-blood group $\mathrm{A} / \mathrm{B}$ versus $\mathrm{H}$ status of human carcinoma cells was correlated with haptotactic cell motility: approach with A and B gene transfection[J]. Cancer Res, 1997, 57:3092-3096.

[61] Bellis SL. Variant glycosylation an under appreciated regulatory mechanism for $\beta 1$ integrins $[\mathrm{J}]$. Biochem Biophys Acta, 2004, 1663: 52-60.

[62] Koscielack J. The hypothesis on function of glycosphingolipids and ABO blood groups revisited[J]. Neurochem Res, 2012,7:1170-1144.

[63] Tsuboi K, Asao T, Ide M, et al.Alphal,2fucosylation 
is a superior predictor of postoperative prognosis for colorectal cancer compared with blood group A, B, or sialyl Lewis $\mathrm{X}$ antigen generated within colorectal tumor tissues[J].Ann Surg Oncol,2007,14(6):1880-1889

[64] Risch HA, Lu L, Wang J, et al.ABO blood group and risk of pancreatic cancer: a study in Shanghai and metaanalysis[J].Am J Epidemiol,2013,177(12):1326-1337

[65] Wolpin BM, Kraft P, Gross M, et al. Pancreatic cancer risk and $\mathrm{ABO}$ blood group alleles: results from the pancreatic cancer cohort consortium[J]. Cancer Res,2010,70(3):1015-1023

[66] Franchini M, Mannucci PM. ABO blood group and thrombotic vascular disease[J].Thromb Haemost,2014, 112(6):1103-1109

[67] Cserti CM, Dzik WH. The ABO blood group system and Plasmodium falciparum malaria[J].Blood, 2007, 110(7):2250-2258

[68] Varki A, Gagneux P. Biological functions of Glycans[M]. 3rd ed. New York: Cold Spring Harbor Laboratory Press, 2015-2017: Chapter 7.

[69] Varki A, Cummings R, Esko J,et al. Essentials of Glycobiology[M]. New York: Cold Spring Harbor Laboratory Press, 1999.

[70] Cooling L. Blood groups in infection and host susceptibility[J]. Clin Microbiol Rev,2015,28(3):801-870

[71] Rowe JA, Handel IG, Thera MA, et al. Blood group O protects against severe Plasmodium falciparum malaria through the mechanism of reduced resetting[J]. PNAS,2007(104):17471-6

[72] Robinson MG,Tolchin D,Halpern C. Entericbacterialagents and the ABOblood groups[J]. Amer J Hum Genet, 1971, 23:135-145.

[73] Wittels EG, Lichtman HC. Blood group incidence and Escherichia coli bacterial sepsis[J].Transfusion, 2005,26(6):533535.

[74] Neil SJD, McKnight A, Gustafsson K, et al. HIV-1 incorporates $\mathrm{ABO}$ histoblood group antigens that sensitize virions to complement-mediated inactivation[J]. Blood, 2005, 105:4693-4699.

[75] Guillon P, Clément M, Sébille V, et al. Inhibition of the interaction between the SARS-CoV spike protein and its cellular receptor by anti-histo-blood group antibodies[J]. Glycobiology, 2008, 18(12):1085-1093

[76] Wang M, Hays T, Ambruso DR, et al.Hemolytic disease of the newborn caused by a high titer anti-group B IgG from a group A mother[J].Pediatr Blood Cancer,2005,45(6):861-862

[77] Jeon H, Calhoun B, Pothiawala M, et al. Significant ABO hemolytic disease of the newborn in a group B infant with a group A2 mother[J]. Immunohematology,2000,16(3):105-108

[78] Haque KM, Rahman M. An unusual case of ABOhaemolytic disease of the newborn[J]. Bangladesh Med Res Counc Bull, 2000, 26(2):61-64

[79] Mollison PL, Engelfriet CP, Contreras M. Blood transfusion in clinical medicine[M]. 10th ed. Blackwell Science: Oxford, UK, 1997
[80] http://www.isbtweb.org [Z].[2018-05-25]

[81] West LJ, Platt JL. And justice for all: consideration of $\mathrm{ABO}$ compatibility in allocation of hearts for infant transplantation[J]. Circulation,2010,121(17):1884-1886

[82] Stewart ZA, Locke JE, Montgomery RA, et al. ABO-incompatible deceased donor liver transplantation in the United States: a National registry analysis[J]. Liver Transpl, 2009, 15(8):883-893

[83] Rowley SD, Donato ML, Bhattacharyya P. Red blood cell-incompatible allogeneic hematopoietic progenitor cell transplantation[J]. Bone Marrow Transplant,2011,46(9):1167-1185

[84] CoolingL.ABO, alemtuzumabandallo-transplantation[J]. Bone Marrow Transplant, 2015, 50:881-883.

[85] Coombs RR, Mourant AE, Race RR. A new test for the detection of weak and incomplete $\mathrm{Rh}$ agglutinins[J]. Br J Exp Pathol,1945,26-255-266

[86] Landsteiner K. Zur Kenntnis der antifermentativen, lytischen und agglutinierenden Wirkungen des Blutserums und der Lymphe[J]. Zentralblatt Bakteriologie, 1900, 27: 357-362.

[87] Janský J. Haematologick studie u psychotiku[J]. Sborn Klinick (in Czech), 1907, 8: 85-139.

[88] Moss WL. Studies on isoagglutinins and isohemolysins[J]. Bulletin Johns Hopkins Hospital, 1910, 21: 63-70.

[89] von Decastello A, Sturli A. Ueber die Isoagglutinine im Serum gesunder und kranker Menschen[J]. Mfinch Med. Wschr, 1902, 49: 1090-1095.

[90] Crow JF. Felix bernstein and the first human marker locus[J].Genetics, 1993, 133(1):4-7

[91] Fiege B, Leuthold M, Parra F, et al. Epitope mapping of histo blood group antigens bound to norovirus VLPs using STD NMR experiments reveals fine details of molecular recognition[J]. Glycoconj $J, 2017,34(5): 679-689$

[92] http://www.rcsb.org/structure/1ZHJ [Z].[2018-0525]

[93] Hosseini-Maaf B, Letts JA, Persson M,et al. Structural basis for red cell phenotypic changes in newly identified, naturally occurring subgroup mutants of the human blood group B glycosyltransferase[J]. Transfusion,2007,47(5): 864-875.

[94] Letts JA, Rose NL, Fang YR, et al. Crystal structure of human $\mathrm{N}$-acetylgalactosaminyltransferase (GTA) complexed with galactose[J]. J Biol Chem, 2006, 281: 3625-3632

[95] http://www.rcsb.org/structure/1ZJ3 [Z].[2018-05-25]

[96] Boix E, Swaminathan GJ, Zhang Y, et al. 53 A Crystal Structure of the Beta-Galactosidealpha-1,3-galactosyltransferase in Complex with UDP[J]. J Biol Chem, 2001, 276: 48608-48614.

[97] Patenaude SI, Seto NOL, Borisova SN,et al. Glycosyltransferase B[J]. Nat Struct Biol, 2002, 9: 685-690.

[98] Misevic GN, BenAssayag G, Rasser B, et al. Design and construction of wall-less nano-electrophoretic 
and nano in micro array high throughput devices for single cell 'omics' single molecule detection analyses[J]. $J$ Mol Struct, 2014, 1073:142-149.

[99] Misevic GN, Rasser B, Norris V, et al. Chemical microscopy of biological samples by dynamic mode secondary ion mass spectrometry[J]. Methods Mol Biol,2009,522:163-173

[100] Popescu O, Misevic GN. Self-recognition by proteoglycans[J]. Nature, 1997, 386(6622):231-232

[101] Dammer U, Popescu O, Wagner P, et al. Binding strength between cell adhesion proteoglycans measured by atomic force microscopy[J]. Science, 1995, 267(521):1173-1175

[102] Misevic GN, Burger MM.Carbohydrate-carbohydrate interactions of a novel acidic glycan can mediate sponge cell adhesion[J]. J Biol Chem, 1993, 268(7):4922-4929

[103] Misevic GN, Finne J, Burger MM. Involvement of carbohydrates as multiple low affinity interaction sites in the self-association of the aggregation factor from the Marine sponge Microciona prolifera[J]. J Biol Chem, 1987, 262(12):5870-5877

[104] Eggens I, Fenderson B, Toyokuni T, et al. Specific interaction between Lex and Lex determinants. A possible basis for cell recognition in preimplantation embryos and in embryonal carcinoma cells[J]. J Biol Chem, 1989, 264(16):9476-9484

(Received 28 May 2018, Revised 07 June 2018, Accepted 11 June 2018) 